\title{
STRATEGI PENGEMBANGAN OBYEK WISATA ALAM BUMI PERKEMAHAN IPUKAN TAMAN NASIONAL GUNUNG CIREMAI
}

\author{
Eki Rusmana $^{1)}$, Nina Herlina ${ }^{2)}$, Iing Nasihin ${ }^{3)}$ \\ ${ }^{1}$ Program Studi Kehutanan, Fakultas Kehutanan Universitas Kuningan \\ 2013071016@uniku.ac.id \\ ${ }^{2}$ Program Studi Kehutanan, Fakultas Kehutanan Universitas Kuningan \\ nina.herlina@uniku.ac.id \\ ${ }^{3}$ Program Studi Kehutanan, Fakultas Kehutanan Universitas Kuningan \\ iing.nasihin@uniku.ac.id
}

\begin{abstract}
Abstrak
Kawasan konservasi yang dimanfaatkan untuk kepentingan wisata alam, salah satunya adalah Taman Nasional Gunung Ciremai (TNGC). Ipukan dimanfaatkan oleh masyarakat sebagai objek wisata alam dan menjadi destinasi wisata yang menawarkan kesejukan dan keasrian udara khas pegunungan. Ipukan sangat cocok untuk aktifitas alam seperti berkemah, tracking, penelitian, pengamatan flora dan fauna. Penelitian bertujuan untuk mengetahui potensi ekowisata serta menentukan strategi pengembangan ekowisata di kawasan Obyek Wisata Alam Bumi Perkemahan Ipukan Taman Nasional Gunung Ciremai. Analisis data dilakukan dengan menggunakan analisis SWOT dengan menghitung bobot dan rating dari EFAS dan IFAS. Buper Ipukan memiliki potensi wisata yang menarik bagi pengunjung seperti: bentang alam, flora dan fauna. Hasil analisis SWOT bahwa potensi wisata alam bumi perkemahan ipukan yang dapat dijadikan daya tarik wisata berupa bentang alam, flora dan fauna. Berdasarkan faktor internal dan eksternal, strategi paling utama untuk diterapkan dalam pengembangan Obyek Wisata Alam Bumi Perkemahan Ipukan adalah strategi menggunakan kekuatan untuk memanfaatkan peluang (Strengths-Oportunities), yaitu dengan tetap mempertahankan kualitas estetika, meningkatkan sarana dan prasarana serta pelayanan dengan tetap mempertahankan aspek kelestarian dan melakukan promosi wisata secara optimal. Salah satu alternatif pengembangan Obyek Wisata Alam Ipukan adalah memperbaiki aksesibilitas, melakukan kerjasama dengan intansi lain dan penambahan sarana wisata.
\end{abstract}

Kata kunci : analisis SWOT; potensi wisata; ipukan; taman nasional

\section{PENDAHULUAN}

Ekowisata adalah kegiatan parawisata yang berwawasan lingkungan dengan mengutamakan aspek kelestarian. Wijayanti (2008) mengemukakan bahwa kegiatan ekowisata berbeda dengan kegiatan pariwisata lainnya. Ekowisata mempunyai karateristik yang spesifik karena adanya kepedulian pada pelestarian lingkungan dan pemberian manfaat ekonomi bagi masyarakat lokal. Pemanfaatan ekowisata hanya dilakukan terhadap aspek jasa estetika, pengetahuan (pendidikan dan penelitian) terhadap ekosistem dan keanekaragaman hayati, serta pemanfaatan jalur untuk tracking dan adventuring (Hakim, 2004).

Guna mengoptimalkan Ekowisata di Bumi Perkemahan Ipukan maka pengembangan ekowisata harus menggunakan kaidah-kaidah yang berkelanjutan yang dapat melindungi kawasan konservasi dan peningkatan perekonomian bagi masyarakat lokal. Perumusan strategi pengembangan ekowisata di kawasan ini sangat penting untuk dilakukan bagi pemanfaatan yang berkelanjutan dan pelestarian keanekaragaman hayati yang dimiliki. 


\section{METODOLOGI PENELITIAN}

\section{Tempat dan Waktu Penelitian}

Penelitian dilaksanakan di kawasan Obyek Wisata Alam Bumi Perkemahan Ipukan TNGC seluas 5 Ha. Pengambilan data lapangan akan dilaksanakan selama satu bulan pada bulan September 2017. Peta lokasi penelitian disajikan pada gambar 3.1.



Gambar 1. Peta Lokasi Penelitian.

\section{Alat dan Bahan}

Alat yang digunakan dalam penelitian ini diantaranya adalah: Alat tulis, Global Positioning System (GPS), Kuisioner, Kamera, Alat perekam suara (recorder). Sedangkan bahan penelitian yang digunakan adalah Obyek Wisata Alam Bumi Perkemahan Ipukan.

\section{Jenis dan Sumber Data}

Data primer adalah data yang diperoleh secara langsung dari lapangan dari objek penelitian atau dari lapangan melalui observasi seperti potensi kawasan, promosi, sarana dan prasarana/fasilitas, potensi bencana alam, aksesibilitas, estetika.

Data sekunder diperoleh dari studi literatur, dan informasi yang ada dilokasi penelitian dan instansi terkait seperti kondisi umum kawasan yang meliputi: kondisi fisik kawasan, kondisi biologi kawasan. Kondisi demografi, sosial dan ekonomi masyarakat sekitar.

\section{Metode Pengumpulan Data}

\section{Studi literatur}

Studi literatur merupakan langkah awal untuk mengetahui kondisi umum lokasi penelitian dan data umum potensi kawasan. Studi literatur diperoleh dari berbagai sumber, seperti skripsi, dokumen, buku atau laporan dari pihak pengelola Obyek Wisata Alam Bumi Perkemahan Ipukan.

\section{Observasi}

Teknik pengambilan data dengan pengamatan langsung di lapangan, pencatatan data dilakukan berdasarkan penemuan langsung di lapangan meliputi data-data potensi kawasan, keadaan fisik kawasan, aksesibilitas. Adapun pengambilan data potensi dengan menggunakan metode eksploratif yaitu survei untuk melakukan penjelajahan di suatu kawasan (Fathoni, 2011). Data yang diambil menggunakan metode eksploratif antara lain: data fauna, dan atraksi wisata. Untuk pengambilan data flora dilakukan analisis vegetasi. Metode yang digunakan adalah metode garis berpetak, dengan ukuran petak $20 \mathrm{~m} \times 20 \mathrm{~m}$, semai $2 \mathrm{~m} \times 2 \mathrm{~m}$, pancang $5 \mathrm{~m} \times 5 \mathrm{~m}$, dan tiang $10 \mathrm{~m} \times 10 \mathrm{~m}$.

\section{Wawancara}

Wawancara diberikan kepada pengelola Obyek Wisata Alam Bumi Perkemahan Ipukan dan dari pihak TNGC untuk mendapatkan informasi terkait rencana pengembangan dan pengelolaan Wisata Alam Ipukan.

\section{Kuisioner}

Kuisioner diberikan kepada pengunjung Obyek Wisata Alam Bumi Perkemahan Ipukan Taman Nasional Gunung Ciremai dan masyarakat sekitar kawasan, penentuan pengunjung dan masyarakat yang dijadikan sebagai obyek penelitian dilakukan dengan teknik penarikan sampel secara acak.

\section{Metode Pengambilan Sampel}

Pengambilan sampel untuk pengelola Obyek Wisata Alam Bumi Perkemahan Ipukan dengan menggunakan metode Porposive Sampling yakni dengan memilih anggota sampel yang mempunyai sifat-sifat yang dimiliki oleh populasi dimana data tersebut diambil. Pengambilan sampel untuk pengelolan Obyek Wisata Alam Bumi Perkemahan Ipukan hanya dilakukan kepada kepala pengelola saja. Pengambilan sampel untuk pengunjung dan masyarakat menggunakan metode simple random sampling yakni dengan memilih sampel secara acak. Indikator yang digunakan untuk menentukan resoden dari pengunjung kriteria dewasa/mampu menjawab kuisioner dengan jumlah responen sebanyak 100 responden.

\section{Metode Analisis Data}

Analisis data dilakukan dengan menggunakan metode Analisis SWOT yang dapat menggambarkan secara jelas bagaimana peluang dan ancaman eksternal yang dihadapi dapat disesuaikan dengan faktor internal 
(kekuatan dan kelemahan) yang dimiliki (Rangkuti 2013).

\section{Penentuan Pembobotan}

Menentukan nilai analisis SWOT dilakukan dengan pembobotan dari hasil penyebaran kuisioner yang diberikan kepada pengunjung, pengelola, dan masyarakat sekitar. Pembobotan tersebut yaitu :

1) Skala pengukuran

Hasil kuisioner yang diberikan kepada pengunjung yang bersifat kualitatif di kuantitatifkan dengan skala mulai dari 3 (sangat penting), sampai 1 (tidak penting). Setelah seluruh hasil kuisioner dihitung kemudian dilanjutkan dengan mengidentifikasi faktor-faktor strategis internal dan eksternal Kawasan Obyek Wisata Alam Bumi Perkemahan Ipukan, dengan menggunakan metode pembobotan (skoring).

Tabel 1. Faktor Internal dan Eksternal

\begin{tabular}{lccc}
\hline Kolom 1 & $\begin{array}{c}\text { Kolom } \\
2\end{array}$ & $\begin{array}{c}\text { Kolom } \\
3\end{array}$ & Kolom 4 \\
\hline $\begin{array}{c}\text { Faktor } \\
\text { eksternal }\end{array}$ & Bobot & Rating & $\begin{array}{c}\text { Skor } \\
\text { Pembobotan }\end{array}$ \\
\hline Peluang & & & \\
Jumlah O & & & \\
Ancaman T & & & \\
Jumlah T & & & \\
Jumlah & & & \\
O+T & & & \\
\hline
\end{tabular}

\section{Matrik Faktor Internal dan Eksternal}

Setelah penghitungan pembobotan selesai dilakukan selanjutnya membuat faktor strategi eksternal dan internal, dengan langkah sebagai berikut:

1) Menentukan faktor - faktor yang menjadi kekuatan serta kelemahan yang terdapat di Obyek Wisata Alam Bumi Perkemahan Ipukan dalam kolom 1 .

2) Memberi bobot masing - masing faktor tersebut dengan skala dari 1,0 (paling penting) sampai 0,0 (tidak penting), berdasarkan pengaruh faktor-faktor tersebut terhadap posisi strategis di Obyek Wisata Alam Bumi Perkemahan ipukan. Semua bobot tersebut jumlahnya tidak lebih dari satu berdasarkan pengaruh dan kondisi Wisata Alam Bumi Perkemahan Ipukan.

3) Menentukan rating, variabel yang bersifat positif (semua yang masuk kategori kekuatan dan peluang) diberi nilai mulai dari +1 sampai dengan +3 (sangat baik), untuk variabel yang bersifat negatif adalah sebaliknya.

4) Kalikan bobot pada kolom 2 dengan rating pada kolom 3.

5) Jumlahkan skor pembobotan untuk memperoleh total skor, untuk menentukan posisi pengembangan dalam kuadran SWOT.

Tabel 2. Faktor Internal dan Eksternal

\begin{tabular}{lccc}
\hline Kolom 1 & Kolom & Kolom & Kolom 4 \\
& 2 & 3 & \\
\hline \multicolumn{1}{c}{ Faktor } & Bobot & Rating & $\begin{array}{c}\text { Skor } \\
\text { internal }\end{array}$ \\
Kekuatan & & & \\
Jumlah S & & & \\
Kelemahan & & & \\
Jumlah W & & & \\
Jumlah & & & \\
S+W & & & \\
\hline
\end{tabular}

Keterangan :

Kolom 1: Faktor-faktor yang dimiliki oleh kawasan wisata diantaranya Kekuatan, Kelemahan, Peluang, dan Ancaman.

Kolom 2: Bobot daripada faktor internal dan eksternal kawasan wisata.

Kolom 3: Rating dari faktor Internal dan eksternal kawasan wisata.

Kolom 4: Skor pembobotan dimana skor pembobotan adalah hasil daripada bobot $\mathrm{x}$ rating.

\section{Membuat kuadran SWOT}

Untuk memetakan posisi pengembangan Kawasan Wisata Alam Bumi Perkemahan Ipukan sebagai berikut :

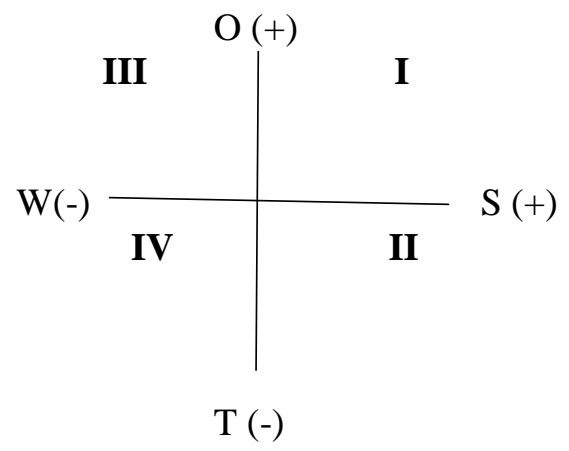

Gambar 2. Posisi strategi Obyek Wisata Alam Bumi Perkemahan Ipukan TNGC 
pada pukul 06:00 hingga pukul 07:00 pagi, maka pelangi akan berada tepat di bawah Curug Cisurian. Gambar Curug Cisurian dapat dilihat pada gambar 5.4.

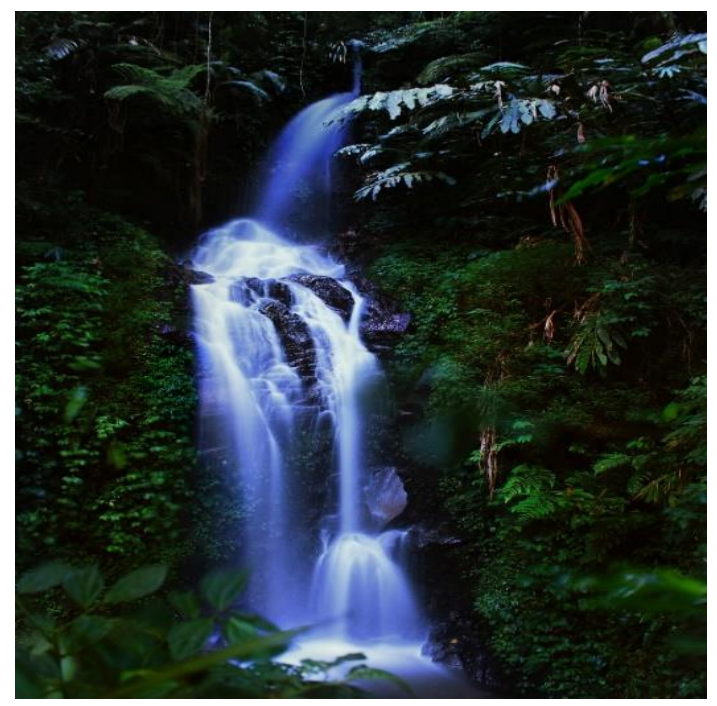

Gambar 3. Curug Cisuria

Curug Cipayung, curug Cipayung memiliki ketiggian $\pm 8 \mathrm{~m}$. Lokasi Curug Cipayung berada dibawah Curug Cisurian. Curug Cipayung dapat ditempuh dengan berjalan kaki selama \pm 10 menit dari parkiran. Untuk masuk Curug Cipayung ini pengunjung akan dikenakan biaya tambahan sebesar rp. 2.000. Keindahan pada Curug Cipayung terletak pada struktur bebatuannya yang berundak-undak dan airnya yang membetuk seperti payung.Gambar Curug Cipayung dapat dilihat pada gambar 5.5.

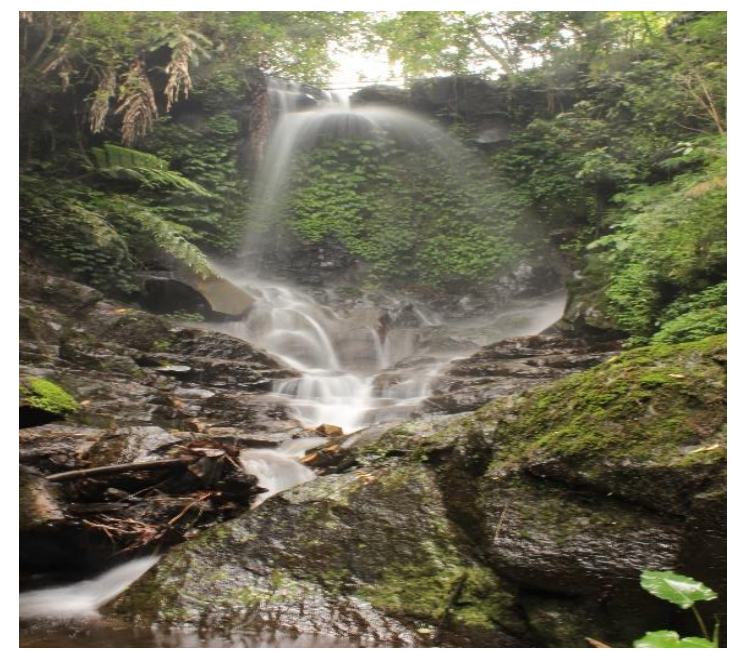

Gambar 4. Curug Cipayung

\section{Flora}

Berdasarkan hasil observasi lapangan jenis flora yang ditemukan di bumi perkemahan
Ipukan sebanyak 36 jenis tumbuhan. Jumlah jenis tumbuhan tingkat semai sebanyak 23 jenis , tingkat tiang sebanyak 17, jenis pancang sebanyak 16 jenis, dan tingkat pohon sebanyak 6 jenis.Tingkat pertumbuhan yang memiliki keanekaragaman paling tinggi adalah tingkat semai, tiang, pancang,dan yang paling rendah adalah tingkat pohon sehingga, rating SWOT bernilai 2, presetasi besarnya kepentingan (bobot) 0,09 dan skor 0.18. Tabel 5.1. Jenis Flora yang ditemukan di Kawasan Obyek Wisata Ipukan.

Tabel 3. Jenis Flora yang ditemukan di Kawasan Obyek Wisata Ipukan.

\begin{tabular}{|c|c|c|}
\hline No & Nama Jenis & \\
\hline 1 & Albasia & Albizia chinensi \\
\hline 2 & Alpukat & Persea americana \\
\hline 3 & Benda & Artocarpus sp. \\
\hline 4 & Beunying & Ficus fistulosa \\
\hline 5 & Bintinu & Melochia umbellata \\
\hline 6 & Darangdang & \\
\hline 7 & Erpatu & \\
\hline 8 & Gintung & Bischofia javanica \\
\hline 9 & Gompong & Schefflera armoatica \\
\hline 10 & Hamberang & Ficus Fulva \\
\hline 11 & Huru & Actinodaphne procera ness. \\
\hline 12 & Kaliandra & $\begin{array}{l}\text { Calliandra callothyrsus } \\
\text { benth }\end{array}$ \\
\hline 13 & Kareumbi & Homalanthus populneus \\
\hline 14 & Kibesi & Rhodamnia cinerea \\
\hline 15 & Kijagong & \\
\hline 16 & Kipare & Glochidion macrocarpus bl \\
\hline 17 & Kiserut & Streblus asper \\
\hline 18 & Kitarasi & \\
\hline 19 & Kondang & $\begin{array}{l}\text { Ficus fistulosa reinw. ex } \\
\text { blume }\end{array}$ \\
\hline 20 & Kopi & Coffea \\
\hline 21 & Kopo & Eugenia cymosa lamk \\
\hline 22 & Kuray & Mallotus panuculatus \\
\hline 23 & Manglid & Manglietia glauca blume \\
\hline 24 & Mara & Macaranga rhicinoides \\
\hline 25 & Mengkudu & Morinda citrifolia \\
\hline 26 & Nangsi & Villebrunea rubescens bl \\
\hline 27 & Pasangdadap & $\begin{array}{l}\text { Lithocarpus indutus } \\
\text { (blume) rehder }\end{array}$ \\
\hline 28 & Pedem & \\
\hline 29 & Pinus & Pinus merkusii \\
\hline 30 & Pulus & Laportea ardens bl \\
\hline 31 & Salam & Syzygium polyanthum \\
\hline 32 & Saninten & Castanopsis argentea a.dc \\
\hline 33 & Tisuk & Hibiscus macrophhyllus \\
\hline 34 & Totongoan & Debregeasia longifolia \\
\hline 35 & Walen & Ficus ribes Reinw \\
\hline
\end{tabular}


Salah satu tumbuhan yang memiliki daya tarik estetika di Buper Ipukan adalah pohon pinus dan pohon saninten. Dapat dilihat pada gambar 5 dan 6.

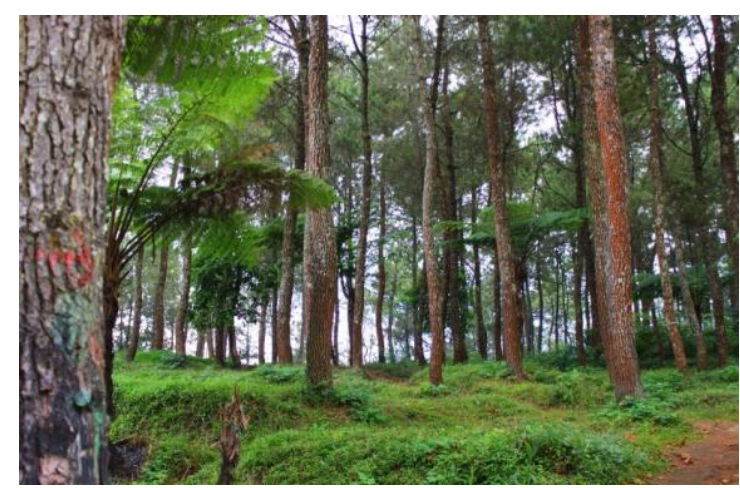

Gambar 5. Pohon Pinus (Pinus merkusii)

Obyek Wisata Alam Bumi Perkemahan Ipukan berada diketinggian 1200 sehiggaa termasuk kedalam ekosiste huta pegunungan. Salah satu ciri vegetasi hutan pegunungan adalah terdapatnya pohon saninten. Saninten adalah sejenis pohon yang bertajuk rimbun, tingginya mencapai $15 \mathrm{~m}$.

Saninten mempunyai buah berbentuk rambutan dan buah saninten bisa dimakan oleh manusia. Tersediannya saninten di Obyek Wisata Ipukan menjadikan sumber makanan bagi satwa liar yang hidup di Ipukan khususnya lutung dan surili. Pohon saninten disajikan pada Gambar 6.

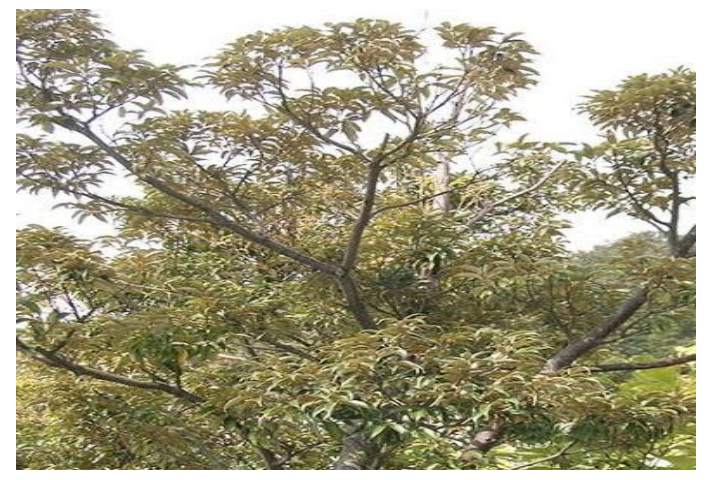

Gambar 6. Pohon saninten

\section{Fauna}

Hasil observasi lapangan, fauna yang ada di Obyek Wisata Ipukan ditemuakan sebanyak 11 jenis.Tabel 5.2. Jenis fauna yang ditemukan di Kawasan Obyek Wisata Ipukan.
Tabel 4. Fauna yang Ditemukan di Kawasan Obyek Wisata Ipukan.

\begin{tabular}{|c|c|c|}
\hline No. & Nama Jenis & Nama Ilmiah \\
\hline 1 & Lutung & Trachypithecus \\
\hline 2 & Surili & Presbytis comata \\
\hline 3 & Garangan & Herpestes javanicus \\
\hline 4 & Kutilang & $\begin{array}{l}\text { Pycnonotus } \\
\text { aurigaster }\end{array}$ \\
\hline 5 & Ciblek & Prinia \\
\hline 6 & Dutdut & $\begin{array}{l}\text { Centropus } \\
\text { nigrorofus }\end{array}$ \\
\hline 7 & Tekukur & Spilopelia chinensis \\
\hline 8 & Elang ular bido & Spilornis cheela \\
\hline 9 & Pentet & Lanius schach \\
\hline 10 & Kacamata & Zosteropidae \\
\hline 11 & $\begin{array}{l}\text { Kolibri } \\
\text { muncang }\end{array}$ & Cinnyris jugularis \\
\hline 12 & Kodok merah & $\begin{array}{l}\text { Leptophryne } \\
\text { cruentata }\end{array}$ \\
\hline
\end{tabular}

Adapun fauna yang hidup di Obyek wisata Ipukan yang memiliki dayatarik wisata yaitu surili, lutung dan kodok merah

\section{Surili dan lutung}

Lutung (Trachypithecus) merupakan satwa endemik Indonesia yang hanya bisa dijumpai di pulau Jawa, Bali, Lombok, Pulau Sempu dan Nusa Barung. Lutung termasuk kedalam katagori hewan yang dilindungi. Kelompok lutung umumnya bergerak dimulai sebelum matahari terbit dan berhenti pada saat sebelum gelap.

Surili yang bernama latin (Presbytis comata) merupakan hewanendemik Jawa Barat. Surili merupaka satwa langka yang dilindungi bahkan sudah termasuk kategori terancam punah.

Keberadaan keduanya merupakan salah satu indikator bahwa kawasan konservasi di Obyek Wisata Ipukan masih cocok bagi keberlangsungan hidup lutung dan surili.Kemunculan lutung dan surili biasanya pagi pukul 05-08 dan sore 03-05. Keberadaan surilidan lutungdi Obyek Wisata Ipukan merupakan salah satu dayatari wisata, karena tidak sedikit pengunjung yang datang hanya untuk melihat kedua primata tersebut. 


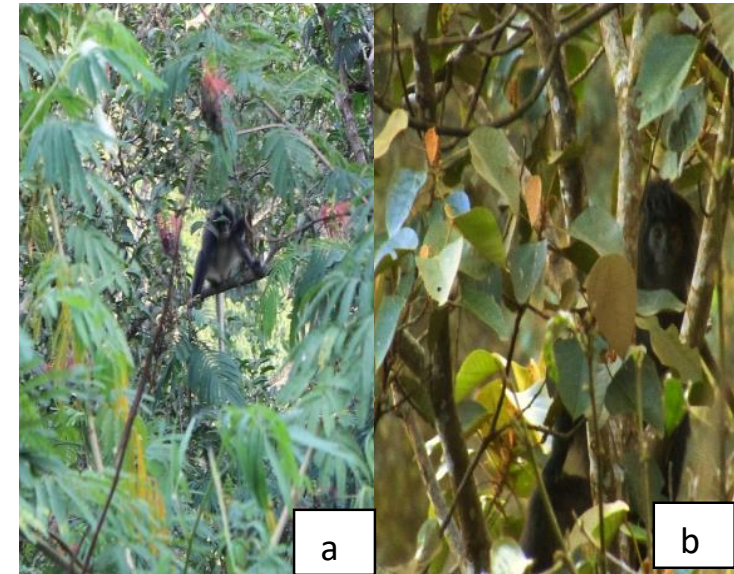

Gambar 7. a. Surili (Presbytis comata). b Lutung (Trachypithecus).

\section{Kodok Merah}

Kodok (Leptophryne cruentata) merah adalah amfibi endemik jawa. Keberadaannya hanya bisa ditemukan di Taman Nasional Gunung Gede Pangrango, Taman Nasional Gunung Halimun Salak dan Taman Nasional Gunung Ciremai. Kodok merah merupakan hewan langka yang dilindungi. Keberadaan Kodok merah di TNGC berlokasi di Obyek Wisata Ipukan yang berhabitat di curug cisurian.

Keberadaan kodok merah di Obyek Wisata Ipukan merupakan aset yang sangat berharga yang harus tetap dipertahankan, karena keberadaanya bisa menjadi daya tarik bagi wisatawan untuk mengunjungi wisata.

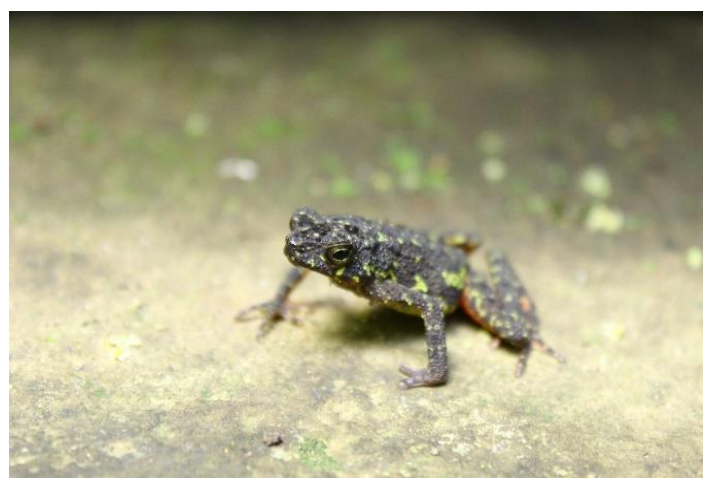

Gambar 8. Kodok Merah (Leptophryne cruentata).

\section{Elag jawa}

Elang jawa (Nisaetus bartelsi) adalah salah satu spesies elang berukuran sedang endemik di Pulau Jawa. Keuinaka satwa ini diidentikan dengan lambang negara Republik Indonesia, yaitu burung garuda. Elang jawa sendiri termasuk satwa langka yang dilindungi.

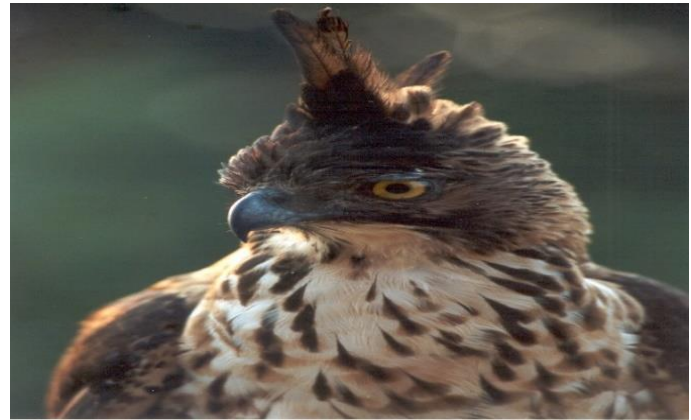

Gambar 9. Elang jawa (Nisaetus bartelsi).

Terdapatnya beberapa satwa langka yang dilindungi dikawasan obyek wisata Ipukan merupakan suatu keuntungan bagi obyek wisata Ipukan, karena bisa menjadi daya tarik wisata untuk dapat menarik minat pengunjung mengunjungi Obyek Wisata Alam Ipukan sehingga, rating SWOT 3, presetasi besarnya kepentingan 0,1 dan skor 0,3 .

\section{Kekuatan \\ Fasilitas}

Kawasan Obyek Wisata yang mampu menarik minat pengunjung salah satunya adalah kelengkapan fasilitas wisata. Adapun fasilitas yang tersedia di obyek wisata Ipukan disajikan pada tabel 5.3

Tabel 5. Fasilitas di Buper Ipukan

\begin{tabular}{llr}
\hline No. & Jenis Fasilitas & Jumlah \\
\hline 1 & Gerbang & 1 \\
& masuk/loket & \\
2 & Mushola & 1 \\
3 & MCK/Toilet & 1 \\
4 & Ruang iformasi & 1 \\
5 & Penyewaan alat & 5 \\
6 & Warung & 2 \\
7 & Tempat parkir & 12 \\
8 & Gazebo & \\
\hline
\end{tabular}

\section{Ketersediaan Air Bersih}

Ketersediaan air bersih di obyek wisata Ipukan cukup tinggi. Hal ini didukung sumber mata air yang cuku besar terdapat di lokasi Curug Cisurian. Air yang berasal dari sumber mata air ditampung terlebih dahulu kedalam bak besar, kemudian disalurkan untuk kebutuhan sumber air bersih bagi pengunjung Obyek Wisata Ipukan dan irigasi sawah masyarakat sekitar. Berdasarkan hasil pengamatan dilapangan ketersediaan air bersih di Obyek Wisata Ipukan cukup tersedia bagi pengunjung maupun masyarakat sekitar sehingga, rating SWOT bernilai 3, presentase besarnya kepentingan (bobot) adalah 0,11 dan skor 0,33. 


\section{Keamanan}

Keamanan dan kenyaman merupakan suatu kondisi yang sangant penting dalam industri keparawisataan. Aspek tersebut mempunyai dampak besar bagi keberlasungan suatu obyek wisata. Keamanan dan kenyamanan wisatawan dapat dipengaruhi dan disebabkan oleh berbagai faktor seperti: bencana alam, perilaku sosial masyarakat, teroris, binatang buas dan lain-lain. Hal tersebut dapat menyebabkan menurunnya rasa aman bagi wisatawan yang berdampak menurunnya jumlah wisatawan. Di obyek wisata Ipukan keamanan dan kenyamanan sangat di perhatikan oleh pengelola. Keamanan dan kenyamanan ketika berada di Obyek Wisata Ipukan sangat terasa oleh pengunjung sehingga, rating SWOT bernilai 3, presentasi besarnya kepentingan (bobot) 0,11 dan skor 0,33.

\section{Kelemahan}

\section{Modal}

Obyek Wisata Alam Bumi Perkemahan Ipukan terletak dikawasan Balai Taman Nasional Gunung Ciremai Provinsi Jawa Barat. Obyek Wisata Alam Ipukan pengelolaannya dibawah pengawasan Balai Taman Nasional Gunung Ciremai yang bekerjasama dengan masyarakat sekitar kawasan wisata. Namun pihak pengelola mengeluhkan dana yang dikeluarkan dari pihak BTNGC kurang memadai untuk kegiatan pengelolaan dan pembangunan obyek wisata Ipukan. Dengan demikian akan meghambat program kegiaatan yang telah direncanakan.

Berdasarkan hasil pengamatan data dilapangan, dukungan dana Buper Ipukan harus dibenahi. Hal ini dibuktikan dengan akses jalan yang buruk yang sagangat dikeluhkan oleh pengunjung sehingga, rating SWOT bernilai 3, presentasi besarnya kepentingan (bobot) 0,11 dan skor 0,33 .

\section{Sarana Wisata}

Obyek wisata identik dengan daya tarik utamanya yaitu keidahan alam dengan diringi sarana wisata yang unik dan menarik, yang bertujuan untuk kepauasan batin dan. Namun hal itu kurang dirasakan oleh pengunjung Ipukan, dikarenakan sarana wisata yang berada di Ipukan kurang memadai. Obyek Wisata Ipukan hanya mengandalkan keidahan panorama alamnya saja, tidak disertai dengan penambahan sarana wisata yang unik dan menarik dari pihak pengelola, seperti di obyek wisata lain yang sedang populer sekarang. Hal ini harus dibenahi oleh pihak pengelola karena kurangnya sarana wisata atan mempengaruhi jumlah wisatawan. Apabila sarana wisata di obyek Wisata Ipukan ditambah kemungkinan besar akan menarik pengunjung untuk datang ke Ipukan.

Berdasarkan hasil pengamatan data dilapangan tentang sarana wisata Ipukan menghasilkan ratin SWOT bernilai 3, presentasi besarnya kepentingan (bobot) 0,0,08 dan skor 0,16.

\section{Kondisi Jalan}

Aksebilitas untuk menuju suatu kawasan wisata yang mempunyai potensi wisata merupakan unsur yang sangat penting karena akan menarik minat pengunjung serta memudahkan untuk mencapai kawasan wisata tersebut. Hal ini sangat disayangkan dengan wisata Ipukan yang memiliki akses yang buruk karna struktur jalan yang bergelombang, dipenuhi batu batu dan kurangnya rambu rambu di dalam kota yang menerangkan bahwa di daerah kaki gunung ciremai terdapat wisata alam yang sangat indah yaitu wisata ipukan.

Berdasarkan hasil pengamatan data dilapangan, akses menuju Buper Ipukan harus segera dibenahi. Hal ini dibuktikan dengan keluhan semua pengunjung, sehingga rating SWOT bernilai 1, presentasi besarnya kepentingan (bobot) 0,12 dan skor 0,12.

\section{Sumber Daya Manusia}

Karyawan pengelola Wisata Ipukan berjumlah 8 orang yang bertindak sebagai pengelola dan tenaga kerja tetap. Jumlah karyawan dan tingkat pendidikan sangat menentukan keberhasila dalam pengelolaan dan pengembangan Obyek Wisata Ipukan, apa lagi jika didukung dengan pelatihan dan pendidikan yang pernah mereka ikuti dalam wisata.

Berdasarkan hasil wawancara dilapangan, pendidikan tenaga kerja Buper Ipukan 2 lulusan SD, 1 lulusan SMP dan 5 lulusan SMA. Maka harus ada penambaha teaga kerja yang mengerti tentang ilmu ekowisata. Rating SWOT bernilai 2, presentasi besarnya kepentingan (bobot) 0,09 dan skor 0,18. 


\section{Peluang}

\section{Minat Pengunjung}

Bagi masyarakat yang memiliki kesibukan yang tinggi terdapat kecenderungan untuk mengisi saat-saat liburan (beristirahat) untuk memelihara kesehatan dan daya tahanya dengan kegiatan-kegiatan yang bermanfaat dan menambah pengetahuan serta wawasan seperti berwisata.

Hasil pengkajian lapangan terhadap pengunjung menunjukan bahwa minat pengunjung mengunjungi obyek Wisata Ipukan utuk melihat keindahannya dan sebanyak 46 responden mengunjungi Obyek Wisata ipukan lebih dari 1 kali dan data yang didapat dari hasil wawancara dengan pengelola jumlah pengunjung yang datang setiap tahunnya mengalami peningkatan yang signifikan, sehingga rating SWOT bernilai 3, presetasi besarnya kepentingan (bobot) 0,15 dan skor 0,45 .

\section{Terbukanya Lapangan Pekerjaan}

Parawisat adalah suatu kegiatan yang secara langsung menyentuh dan melibatkan masyarakat, sehingga membawa berbagai manfaat terhadap masyarakat setempat dan sekitarnya. Manfaat dari obyek wisata dapat dilihat dari berbagi aspek /segi ekonomi, sosial budaya, lingkungan hidup, ilmu pengetahuan, peluang dan kesempatan kerja.

Hasil wawancara dengan masyarakat sebanyak $80 \%$ masyarakat menyatakan dengan dijadikannya Ipukan sebagai obyek wisata, masyarakat merasakan dampak positif dengan terbukanya lapangan pekerjaan dan bertambahnya pendapatan, sehingga rating SWOT bernilai 2, presetasi besarnya kepentingan (bobot) 0,07 dan skor 0,14.

\section{Media Sosial}

Media sosial adalah sebuah media untuk bersosialisasi satu sama lain dengan dilakukan secara online yang memungkinkan manusia untuk saling berinteraksi tanpa dibatasi ruang dan waktu. Keuntungan dari media sosial yaitu dapat dilakukan kapan saja dan dimana saja berada selagi akses internet bisa terhubung contoh konkritnya adalah promosi dari media sosial melalu instagram, caranya dengan memphoto spot menarik lalu meng upload di instagram dengan memberikan caption menarik hal ini dapat menarik minat warga agar datang ke tempat wisata ipukan. Menjamurnnya penggunaan mediasosial pada saat ini berdampak besar bagi kehidupan manusia karena sosial media sudah menjadi bagian yang tidak bisa dipisahkan dalam kehidupan.

Berkembangnya media sosial yang begitu peasat, merupakan peluang yang dapat dimanfaatkan oleh Obyek Wisata Ipukan untuk memasarkan, memberi informasi dan memasyarakatkan Buper Ipukan secara lebih luas. Dari banyaknya pengguan media sosial berpeluang menarik pengunjung untuk menjadikan Ipukan sebagai destinasi wisatanya, sehingga rating SWOT bernilai 4, presetasi besarnya kepentingan (bobot) 0,15 dan skor 0,6.

\section{Dukungan Masyarakat Sekitar}

Berdasarkan hasil penelitian, terdapat beberapa jenis usaha dibidang wisata yang telah berjalan oleh masyarakat setempat dikawasan Obyek Wisata Ipukan. Keberadaan Buper Ipukan mempengaruhi aspek sosial ekonomi yang sangat berarti bagi masyarakat, dengan menjadikan kawasan wisata sebagai daerah penghidupan dan dapat meningkatkan pendapatan. Jenis usaha tersebut meliputi usaha di bidang transportasi (ojek), konsumsi (warung makan dan minum) dan jasa (penyewaan peralatan berkemah, pendamping lapangandan penitipan kendaraan). Dukungan dari masyarakat sekitar merupakan suatu keuntungan, sehingga rating SWOT bernilai 3, presetasi besarnya kepentingan (bobot) 0,1 dan skor 0,3 .

\section{Penambahan Fasilitas Obyek Wisata}

Kegiatan wisata alam untuk saat ini merupakan salah satu bentuk usaha yang menjanjikan karena kebutuhan untuk berwisata, berekreasi dan menghasilkan suatu karya seni kreatif telah menjadi kebutuhan gaya hidup bagi sebagian orang. Obyek Wisata Ipukan terkenal akan keindahan alamnya seperti: pemandangan pematang sawah/ pertanian, bukit, bangunanbangunan kota, hutan belantara, lembah ipukan, sunrise/matahari terbit, dan lampu lampu kota ketika malam hari. Namun hal tersebut masih terasa kurang dimata pengunjung dan karyawan ipukan.

Untuk dapat menarik minat pengunjung, perubahan dan renovasi adalah bentuk nyata yang harus dilakukan oleh Buper Ipukan, misalkan memperbaiki sarana taman ipukan seperti kayu yang sudah tidak layak. Apabila Sarana wisata yang ada di obyek wisata Ipukan 
sudah masimal hal ini dapat memikat daya tarik wisatawan, hal ini harus segera dibenahi pihak pengelola agar obyek wisata Ipukan bisa setara dengan wisata lain bahkan menjadi wisata unggulan di Kabupaten Kuningan, sehingga rating SWOT bernilai 3, presetasi besarnya kepentingan (bobot) 0,07 dan skor 0,21 .

\section{Ancaman}

\section{Pencemaran lingkungan}

Membahas tentang pencemaran lingkungan merupakan musuh utama industri wisata. Semakin sukses Obyek Wisata, semakin besar pula bahaya pencemarannya. Salah satu bentuk pencemaran lingkungan yang ada di Obyek Wisata Ipukan adalah limbah pelastik yang dihasilkan dari kegiatan wisatawan. Masalah ini terjadi akibat kuranngnya pengetahuan dan kesadaran pengunjung terhadap kelestarian lingkungan. Untuk mengatasi masalah pencemaran lingkungan pihak dari Buper Ipukan biasanya selalu membersihkan lingkungan setelah kegiatan pengunjung selesai sehingga dan setiap sore hari pihak pengelola selalu membersihkan tempat wisata ipukan secara rutin, rating SWOT bernilai 3, presetasi besarnya kepentingan (bobot) 0,07 dan skor 0,21 .

\section{Tekanan sosial ekonomi masyarakat}

Tekanan sosial ekonomi masyarakat khususnya disebabkan dengan adanya persaingan, keleluasaan dan kecemburuan sosial antara kelompok masyarakat yang satu dengan yang lainnya. Dari hasil kuisioner masyarakat sekitar yang memiliki tingkat ekonomi sosial katagori cukup sebanyak $80 \%$. Sedangkan apabila obyek wisata dalam keadaan ramai, sebagian responden menyatakan tidak mempengaruhi pendapatan mereka oleh karna itu hal ini menyebabkan kesenjangan sosial yang begitu nampak yang berdampak kepada masrayarakat yang tidak ikut andil dalam kepengurusan wisata ipukan tidak mendapat keuntungan yang berarti begitupun terdapat tekanan sosial yang disebabkan oleh persaingan, kecemburuan sosial antara kelompok masyarakat yang cukup besar, seingga rating SWOT bernilai 3, presetasi besarnya kepentingan (bobot) 0,1 dan skor 0,3 . Seharusnya permasalahan ini harus segera di atasi dengan cara memberdayakan seluruh masyarakat sekitar wisata ipukan melalui karang taruna untuk lebih memajukan wisata ipukan.

\section{Persaingan Obyek Wisata}

Kawasan obyek wisata Alam yang terdapat di Kabupaten Kuningan selain Obyek wisata Bumi Perkemahan Ipukan antara lain Waduk Darma, Telaga Remis, Paniis, Balong Dalem, Tenjo Laut, Buper Palutungan, Taman Sukageuri, Gunung Batu Mayasih, Kebun Raya Kuningan. Hal ini menyebabkan persaingan atara obyek wisata, sehingga mengurangi jumlah wisatawan yang datang. Keadaan seperti ini harus dijadikan sebagai motivasi bagi Obyek Wisata Ipukan untuk lebih meningkatkan upaya pengembangan, peningkatan kualitas kawasan baik dari segi ekologi, segi ekonomi, dan segi budaya agar Obyek Wisata Ipukan sejajar dengan wisata lain yang lebih populer.

Berdasarkan hasil penelitian dilapangan Buper Ipukan masih unggul dibandingkan dengan wisata lain, hal ini dilihat dari jumlah penjualan tiket masuk dan bertambahnya jumlah pengunjung yang datang setiap tahunnya. Namun dengan banyak tempat obyek wisata dan dibukanya obyek wisata baru di Kabupaten Kuningan bisa menjadi ancaman yang serius, sehingga rating SWOT bernilai 1, presetasi besarnya kepentingan (bobot) 0,12 dan skor 012.

\section{Vandalisme}

Kegiatan vandalisme merupakan ancaman yang dapat merusak keadaan estetika, fasilitas dan kenyamanan pada kawasan wisata. Dengan usaha-usaha yang kooperatif pada pengunjung, masyarakat dan petugas diharapkan dapat membuat kawasan yang nyaman sesuai dengan tujuan keberadaan kawasan wisata sebagai tempat berrekreasi.

Salah satu contoh vandalisme yang ada di Obyek Wisata Alam Ipukan adalah pencoretan batu dan sebagian fasilitas kawasan wana wisata Ipukan. Dengan vandalisme yang ada dikawasan ini akan menurunkan keindahan dan kenyamanan sehingga pengunjung enggan untuk datang kembali, sehingga rating SWOT bernilai 3 , presetasi besarnya kepentingan (bobot) 0,07 dan skor 0,21.

\section{Keselamatan Pengunjung}

Secara umum keselamatan pengunjung selalu diutamakan. Dampak dari peningkatan pengelolaan Obyek Wisata Ipukan yang dapat dirasakan secara langsung adalah himbauan 
kepada pengunjung ketika cuaca sedang hujan dilarang memainkan hp, dikarenaka Obyek wisata Ipukan rawan dengan petir ketika cuaca sedang tidak baik. Adapun upaya lain yang dilakukan pengelola untuk keselamatan pengunjung berupa jembatan sederhana yang bertujuan untuk memudahkan pengunjung mencapai lokasi curug.

\section{Analisis Matrik Faktor Strategi Internal dan Eksternal}

Setelah faktor-faktor strategis internal dan eksternal teridentifikasi maka dibuatlah tabel IFAS (Internal Factors Analysis Summary) untuk merumuskan faktor-faktor strategi
Dari hasil kuisioner $90 \%$ pengunjung menyatakan rasa aman ketika mengunjungi Buper Ipukan meskipun pernah terjadi kejadian yang merenggut nyawa pengunjung oleh sambaran petir. Namun pengunjung beranggapan bahwa hal tersebut tidak mutlak kesalahan dari pengelola melainkan kesalahan dari pengunjungnya sendiri, sehingga, rating SWOT bernilai 3, presetasi besarnya kepentingan (bobot) 0,1 dan skor 0,3 .

internal dalam kerangka Strengths dan Weaknesses serta tabel EFAS (Eksternal Factors Analysis Summary) untuk merumuskann faktor-faktor strategi eksternal dalam kerangka Opportunities dan Threats. Tabel IFAS dan EFAS dapat dilihat pada Tabel 3.5 dan 3.6.

Tabel 7. IFAS (Internal Factors Analysis Summary)

\begin{tabular}{|c|c|c|c|c|}
\hline No & $\begin{array}{c}\text { Faktor interal } \\
\text { Kekuatan }(\text { Strength } / S)\end{array}$ & Bobot & Rating & Skor \\
\hline 1 & Bentang alam & 0,13 & 4 & 0,52 \\
\hline 2 & Flora & 0,09 & 2 & 0,18 \\
\hline 3 & Fauna & 0,1 & 3 & 0.30 \\
\hline 4 & Fasilitas & 0,09 & 2 & 0,18 \\
\hline 5 & Ketersediaan air bersih & 0,11 & 3 & 0,33 \\
\hline \multirow[t]{2}{*}{6} & Keamanan & 0,11 & 3 & 0,33 \\
\hline & Jumlah S & & & 1,54 \\
\hline No & Kelemahan (Weakness/W) & & & \\
\hline 1 & Modal & 0,08 & 2 & 0,16 \\
\hline 2 & Sarana wisata & 0,08 & 3 & 0,24 \\
\hline 3 & Kondisi jalan & 0,12 & 1 & 0,12 \\
\hline \multirow[t]{3}{*}{4} & Sumberdaya manusia & 0,09 & 2 & 0,18 \\
\hline & Jumlah W & & & 0,7 \\
\hline & & 1 & & 2,24 \\
\hline \multicolumn{5}{|c|}{ Tabel 8. EFAS (Eksternal Factors Analysis Summary) } \\
\hline No & $\begin{array}{c}\text { Faktor exteral } \\
\text { Peluang (Opportunities/O) }\end{array}$ & Bobot & Rating & Skor \\
\hline 1 & Minat pengunjung yang tinggi & 0,15 & 3 & 0,45 \\
\hline 2 & terbukanya lapangan pekerjaan & 0,07 & 2 & 0,14 \\
\hline 3 & Media sosial & 0,15 & 4 & 0,6 \\
\hline 4 & Dukungan masyarakat sekitar & 0,1 & 3 & 0,3 \\
\hline \multirow[t]{3}{*}{5} & Penambahan fasilitas & 0,07 & 3 & 0,21 \\
\hline & Jumlah O & & & 1,7 \\
\hline & Ancama (Treaths/T) & & & \\
\hline 1 & Persaingan obyek wisata & 0,12 & 1 & 0,12 \\
\hline 2 & Pencemaran lingkungan & 0,07 & 3 & 0,21 \\
\hline 3 & Tekanan sosial masyarakat & 0,1 & 3 & 0,3 \\
\hline 4 & Vandalisme & 0,07 & 3 & 0,21 \\
\hline \multirow[t]{2}{*}{5} & Keselamatan pengunjung & 0,1 & 3 & 0,3 \\
\hline & & 1 & & 1,14 \\
\hline
\end{tabular}


Berdasarkan tabel diatas dapat diketahui bahwa skor untuk faktor internal adalah 1,54 dan skor untuk faktor eksternal adalah 1,7 dengan demikian posisi pengembangan berada pada kuadran I. Posisi tersebut dapat di lihat pada gambar 10.

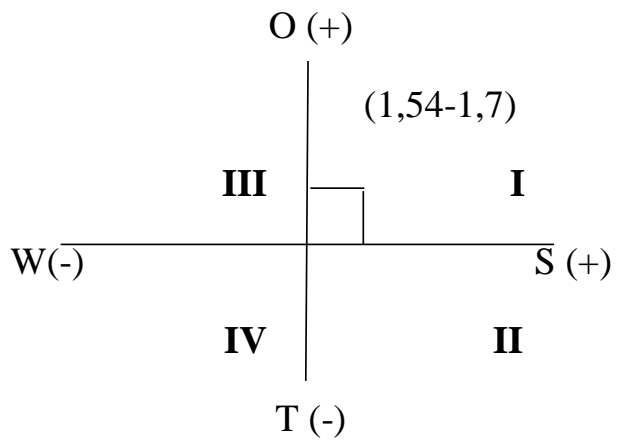

Gambar 10. Posisi pengembangan Buper Ipukan TNGC

Hasil analisis ini menunjukan situasi yang sangat menguntungkan, artinya suatu kawasan wisata tersebut memiliki peluang dan kekuatan sehingga dapat memanfaatkan peluang yang ada. Berdasarkan hasil kuadran analisis SWOT maka strategi yang tepat untuk Pengembangan Obyek Wisata Bumi Perkemahan Ipukan adalah Strategi SO (Strength Opportunities).

Startegi SO yaitu menciptakan strategi dengan menggunakan kekuatan yang dimiliki untuk memanfaatkan peluang. Strategi SO yang dapat digunakan yaitu: Memelihara kualitas estetika, Meningkatkan kualitas sarana dan prasarana serta pelayanan dengan tetap mempertimbangkan aspek lingkungan, Mengenalkan atau mempromosikan sumber daya wisata yang ada di Ipukan.

\section{Strategi Alternatif Pengelolaan Obyek Wisata Alam Ipukan}

Berdasarkan analisis SWOT, terhadap faktor IFAS dan EFAS, maka kekuatan, kelemahan, peluang, dan tantangan dapat dianalisis untuk dirumuskan suatu upaya tindak lanjut untuk mengatasi dan mengoptimalkannya. Kombinasi antara kekuatan-peluang, kekuatan-ancaman, kelemahan-peluang, dan kelemahan-ancaman dapat memunculkan suatu upaya untuk melengkapi ketidaksempurnaan kondisi internal dan eksternal dalam bentuk pernyataan alternatif strategi. Gambar berikut memperlihatkan alternatif-alternatif strategi dalam bentuk matriks SWOT.

Dengan merujuk pada gambar 11 maka dapat dirumuskan alternatif strategi pengembangan ekowisata obyek wisata Ipukan yaitu: memperbaiki aksesibilitas, melakukan kerjasama dengan intansi lain, dan penambahan sarana wisata

\begin{tabular}{|l|l|l|}
\hline INTERNAL & STRENGTHS (S) & WEAKNESSES (W) \\
& (KEKUATAN) & 1. Modal \\
& 2. Bentang alam & 2. Sarana wisata \\
& 3. Flora & 3. Aksesibilitas \\
3. Fauna & 4. Sumber daya manusi \\
EKSTERNAL & Fasilitas Keamanan pengunjung & \\
\hline
\end{tabular}




\begin{tabular}{|c|c|c|c|c|}
\hline \multirow[t]{2}{*}{$\begin{array}{l}\text { OPPORTUNITIES }(\mathrm{O}) \\
\text { (PELUANG) } \\
\text { 1. Minat pengunjung yang } \\
\text { tinggi } \\
\text { 2. Terbukanya lapangan } \\
\text { pekerjaan } \\
\text { 3. Media sosial } \\
\text { 4. Dukungan masyarakat } \\
\text { 5ekitar } \\
\text { 5. Penambahan fasilitas }\end{array}$} & \multicolumn{2}{|c|}{$\begin{array}{l}\text { STRATEGI SO } \\
\text { 1. Memelihara kualitas } \\
\text { estetika } \\
\text { 2. Meningkatkan sarana dan } \\
\text { prasarana serta pelayanan } \\
\text { dengan tetap } \\
\text { mempertimbangkan } \\
\text { aspek lingkungan } \\
\text { 3. Mempromosikan } \\
\text { sumberdaya } \\
\text { wisata yang ada }\end{array}$} & \multicolumn{2}{|c|}{$\begin{array}{ll}\text { STRATEGI WO } \\
\text { 1. } & \text { Meningkatkan kualitas } \\
& \text { pengelolaan obyek } \\
& \text { wisata } \\
\text { 2. } & \text { Meningkatkan } \\
& \text { kerjasama dengan } \\
\text { masyarakat sekitar } & \text { dalam upaya } \\
\text { pengelolaan kawasan } \\
\text { 3. } \\
\text { Melakukan promosi } \\
\text { secara optimal }\end{array}$} \\
\hline & & \multicolumn{2}{|c|}{ Rekomendasi: } & \\
\hline 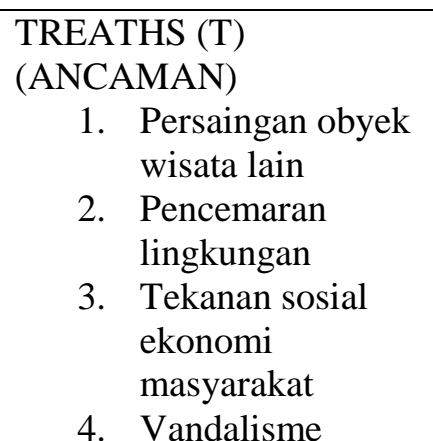 & $\begin{array}{ll}\text { STRATEGI ST } \\
\text { 1. } \\
\text { Memperbanyak } \\
\text { papan informasi, } \\
\text { larangan } \\
\text { /peringatan bagi } \\
\text { pengunjung } \\
\text { 2. } \\
\text { Meningkatkan } \\
\text { kerjasama } \\
\text { dengan } \\
\text { masvarakat }\end{array}$ & \multicolumn{2}{|c|}{$\begin{array}{l}\text { 1. Memperbaiki } \\
\text { aksesibilitas } \\
\text { 2. Melakukan } \\
\text { kerjasama } \\
\text { dengan intansi } \\
\text { lain } \\
\text { 3. Penambahan } \\
\text { sarana wisata }\end{array}$} & $\begin{array}{l}\text { STRATEGI } \\
\text { WT } \\
\text { 1. Menjaga } \\
\text { kelestarian } \\
\text { kawasan } \\
\text { baik oleh } \\
\text { pengunjung, } \\
\text { pengelola } \\
\text { maupun } \\
\text { masvarakat }\end{array}$ \\
\hline $\begin{array}{l}\text { 5. Keselamatan } \\
\text { pengunjung }\end{array}$ & $\begin{array}{l}\text { 3. Meningkatkan } \\
\text { pengawasan bagi } \\
\text { pengunjung }\end{array}$ & & \multicolumn{2}{|c|}{$\begin{array}{l}\text { 2. Bekerjasama dengan } \\
\text { investor dan agen- } \\
\text { agen wisata serta } \\
\text { memperbanyak } \\
\text { promosi dengan } \\
\text { membuat paket wisata } \\
\text { yang menarik }\end{array}$} \\
\hline
\end{tabular}

Gambar 11. Matrik SWOT Strategi Pengembangan Obyek Wisata Alam Bumi Perkemahan Leles

\section{SIMPULAN}

1. Potensi Obyek Wisata Alam Bumi Perkemahan Ipukan yang dapat dijadikan sebagai daya tarik wisata berupa bentang alam, flora, dan fauna.

2. Strategi yang diterapkan dalam pengembangan obyek wisata alam bumi perkemahan Ipukan adalah strategi SO yaitu strategi menggunakan kekuatan yang dimiliki untuk memanfaatkan peluang. Strategi SO yang dapat digunakan yaitu: Memelihara kualitas estetika, Meningkatkan kualitas sarana dan prasarana serta pelayanan dengan tetap mempertimbangkan aspek lingkungan, Mengenalkan atau mempromosikan sumberdaya wisata yang ada di Ipukan.

\section{REFERENSI}

Ading. 2010. Studi Pengembangan Faktor Internal dan Eksternal Kawasan Wisata Alam
Lembah Cilengkrang Kabupaten Kuningan. Skripsi. Fakultas Kehutanan, Universitas Kuningan. Kuningan

BTNGC. 2013. Launcing Bumi Perkemahan Ipukan.http://tngciremai.com.

BTNGC. 2016. Menuju Manajemen Paripurna Pengelolaan Taman Nasional Gunung Ciremai Untuk Kedaulatan Rakyat. Kementrian Lingkungan Hidup dan Kehutanan Direktorat Jenderal Konservasi Sumber Daya Alam dan Ekosistem BTNGC. Kuningan: BTNGC.

Dephut. 2008, 30 Juni 2017. Kemungkinan Meningkatkan Ekowisata. http://www.dephut.go.id.

Fandeli, C. 2000). Pengusahaan ekowisata. Fakultas Kehutanan UGM.Yogyakarta

Flamin, dan Asnaryati. 2013. Potensi Ekowisata dan Strategi Pengembangan Tahura Nipa-nipa, Kendari, Sulawesi Tenggara. 
Penelitian Kehutanan Wallacea. Vol 2 No 2.154-168.

Hakim L, 2004. Dasar-dasar Ekowisata. Bayumedia Publihsing, Malang.

Honey M, 1999. Ecotourism and Sustainabele Development. Who owns Paradise? Island Press, Washington D.C.

KEHATI, 2000. Materi Kursus Inventarisasi Flora dan Fauna Taman Nasional Meru Blitar, Malang

Kementerian Lingkungan Hidup dan Kehutanan. 2015. Statistik Kementerian Lingkungan Hidup dan Kehutanan 2014. Kementerian Lingkungan Hidup dan Kehutanan, Jakarta.

Ko, RKT, 2001. Obyek Wisata Alam Pedoman Identifikasi Pengembangan, Pengelolaan, Pemeliharaan dan Pemasarannya. Yayasan Buena Vista Cisarua, Bogor.

Marpung, H, 2002. Pengetahuaan Keparawisataaan. Alfabeta, Bandung.

Muntasib EKSH. 2003. Interpretasi Wisata Alam. Laboratorium Rekreasi Alam Departemen Konservasi Sumberdaya Hutan Fakultas Kehutanan IPB, Bogor.

Muttaqin, 2011. Kajian Potensi dan Strategi Pengembangan di Cagar Alam Pulau Sempu Kabupaten MalangJawa Timur. GAMMA 6 (2). $152-161$.

Nurfatriani F, Efida YS. 2003. Pengelolaan Ekowisata Berbasis Masyarakat Lokal. Buletin Penelitian dan Pengembangan Kehutanan. Vol 4 No 1. 31-39.

Oktadiyani P, Iwanuddin dan Helwinsyah. 2015. Strategi Pengembangan Wisata Alam Taman Wisata Alam Wera. Jurnal WASIAN. Vol 2 No 1.9-10.

Pulungan, S. 2013. Optimasi Pengembangan Ekowisata Sebagai Objek Wisata Andalan di Kabupaten Kutai Kartanegara Kalimantan Barat. Jurnal Bina Praja. 5 (3). 205-2014.
Rangkuti, F. 2003. Analisis SWOT: Teknik Membedah Kasus Bisnis-Reorientasi Konsep Perncanaan Strategi Untuk Menghadapi Abad 21. Gramedia Pustaka Utama, Jakarta.

Rangkuti, F. 2004. Analisis SWOT Teknik Membedah Kasus Bisnis. PT. Gramedia Pusaka Utama, Jakarta

Rangkuti, F. 2006. Analisis SWOT Teknik Membedah Kasus Bisnis. PT. Gramedia Pusaka Utama, Jakarta.

Razak, A. 2008. Sifat dan Karakter Objek dan Daya Tarik Wisata Alam. Skripsi. Universits Gadjah Mada, Yogyakarta.

Slovin, M. J.1960. Sampling. Simon and Schuster Inc, New York.

Soemarwoto, G. 2010. Analisa Dampak Lingkungan. Gadjahmada University Press, Yogyakarta.

Suhandi, AS. 2003. Ekowisata, Peluang dan Tantangan.

http://www.dieny-yusuf.com. 27 Juni

Suyitno, 1999. Perencanaan Wisata. Kanisius, Yogyakarta.

The International Ecotourism Society. 2005. Fact Sheet:Global Tourism. Washington: The international Ecotourism Society. www.ecotourism.org. Juni 28

The Quebec Declarationon Tourism. 2002 Juni 28. Quebec Declarationon Tourism. Quebec City. World Tourism Summit. www.ecotourism.org.

[UNWTO] United Nations World Tourism Organization. 2015. Annual Report 2014. World Tourism Organization, Madrid.

Waluyo H. 2007. Pengembangan Kepariwisataan Indonesia. http.//www.budpar.co.id. Juni 30

Wijayanti, P. 2008. Analisis Ekonomi dan Strategi Pengelolaan Ekowisata. Studi kasus kawasan wisata gunung salak endah. Jurnal Ilmu Pertanian Indonesia. 13 (3).173-181. 